\title{
Ángel Felices Lago \& Cecilia Ruiz López: Español para el comercio internacional. Madrid: Editorial Edinumen, 1998
}

Hvert år i september ved semesterstart føler mangen en lærer i spansk fagligt sprog på BA ærgrelse over manglen på velegnede spanske lærebøger inden for dette område og ikke sjældent misundelse over, at kollegerne i engelsk bare kan vælge og vrage mellem utallige udgivelser. Det var derfor med stor spænding, jeg modtog ovennævnte publikation, som netop i sin indledning understreger misforholdet mellem antallet af lærebøger med fagligt indhold på henholdsvis engelsk og spansk, og det til trods for, at spansk dog er et af de sprog, som tales mest i verden. Bl.a. for således at give den spanskstuderende flere muligheder at vælge imellem har forfatterne følt sig tilskyndet til at udarbejde denne lærebog, som er på 198 sider, inklusive et glossar med definitioner på 28 sider. Dertil hører et bind med 63 sider rettenøgler.

Forfatternes pædagogiske sigte med lærebogen er at fremme den studerendes aktive indlæring af de almindeligste spanske termer og udtryk inden for emnet udenrigshandel, idet sværhedsgraden gradvist øges igennem de tematiske kapitler, som der er 7 af: 1. Introducción al comercio; 2. La empresa comercial: Su naturaleza jurídica; 3. La decisión de exportar o importar; 4. Políticas de exportación; 5. Los medios de pago; 6. Los documentos de exportación-importación og 7. El transporte internacional de mercancías. Temaerne er anført i en logisk og sekventiel rækkefølge og giver den studerende mulighed for at gøre sig bekendt med pragmatiske, sociale og kulturelle aspekter i forbindelse med en spansk virksomhed, fra dens spæde begyndelse til dens konsolidering som eksportvirksomhed.

Hvert kapitel omhandler typisk 4 deltemaer, hvoraf de to behandles i en dia$\log$ mellem hovedpersonen i kapitlerne og henholdsvis en rådgiver og hovedpersonens datter. Efter hvert deltema følger forskellige praktiske øvelser med henblik på genkendelse og reproduktion af termer og udtryk. De 7 tematiske kapitler efterfølges af 11 siders repetitionsøvelser samt 6 bearbejdede nyere avisartikler om forskellige aspekter ved Spaniens udenrigshandel, som kan danne udgangspunkt for diskussioner mellem de studerende.

Lærebogens målgruppe anføres at være studerende med mellemhøjt, højt eller meget højt niveau i spansk, og til disses beroligelse anfører forfatterne, at de ikke behøver forudgående studier i økonomi eller handel for at kunne benytte bogen, på samme måde som det heller ikke er nødvendigt, at læreren har nogen større viden om de behandlede emner, idet vanskeligheder kan løses ved opslag i definitionsglossaret!

Med forventningens glæde går jeg da ombord i de to bind. Umiddelbart virker det overvældende, at forfatterne kan presse så mange forskellige termer og udtryk ind i en eller anden form for kontekst. I ét kapitel kan der i forbindelse 
med de 4 deltemaer, der normalt fylder ca. 1 side hver, berøres op til 100 forskellige termer og udtryk. Det er naturligvis med henblik herpå, at dialogformen benyttes i idstralt grad, da denne form jo netop giver mulighed for, at den adspurgte kan belære den spørgende om mangt og meget, hvilket dog i længden giver en noget kunstig dialog.

En del af de praktiske $\emptyset$ velser rummer tilfredsstillende udfordringer i den forstand, at de kun kan løses, såfremt den studerende har begrebet termens indhold. I andre af øvelserne lægges der imidlertid op til gold reproduktion, når spørgsmålene helt ubesværet kan besvares ved, at man kaster et hurtigt blik på den foregående side, hvor termerne meget bekvemt er sat med fed skrift, og når rettenøglen som løsning kun accepterer formuleringer fra artiklen. Som eksempel herpå kan nævnes følgende spørgsmål p. 129: ¿Qué riesgos cubre el seguro de mercancías? Der kræves ikke megen fantasi og omtanke for at kunne besvare dette spørgsmål, da rettenøglen kun accepterer følgende svar: Los que puedan darse desde el embarque hasta la descarga de la mercancía, og som blot er en let omformulering af artiklens ... los riesgos que puedan sufrir desde su embarque hasta su descarga (p. 128). Bag denne form for praktiske øvelser anes den gamle spanske akademiske tradition med eksamination udelukkende på basis af apuntes taget under forelæsningerne.

Mange forskellige temaer behandles på meget begrænset plads, og resultatet er desværre mange eksempler på overfladiskhed og unøjagtigheder som fx følgende:

Mayoristas: Comerciantes que venden grandes cantidades de un producto (p. 189)

venta en firme benyttes synonymt med pago al contado (p. 22)

Om aktiekapitalen hævdes p. 36, at

... el capital se suscribe en su totalidad y se desembolsa en una cuarta parte ...

Herom anfører den spanske aktieselskabslov i § 12:

No podrá constituirse sociedad alguna que no tenga su capital suscrito totalmente y desembolsado en una cuarta parte, por lo menos, el valor nominal de cada una de sus acciones.

balance benyttes i betydningen årsregnskab (p. 37).

Af deciderede fejlagtige oplysninger kan fx nævnes:

Esta última [la Junta General] tendrá la obligación de convocar, al menos una vez al año, la Junta General Ordinaria de Accionistas (p. $37)$.

Et opslag i den spanske aktieselskabslov viser noget andet, idet der i § 94 står:

Las juntas generales podrán ser ordinarias o extraordinarias y habrán de ser convocadas por los administradores de la sociedad. 
Om revisorer i aktieselskaber anføres p. 37:

Las sociedades anónimas tienen que verificar las cuentas anuales por medio de censores de cuentas que deben ser accionistas y no pueden pertenecer al Consejo ni ser parientes de ninguno de sus miembros. También se nombrará a auditores externos para hacer la misma labor...

Denne ordning ophørte imidlertid i 1988 med den nye lov om revision.

Om vekselprotest står følgende p. 82:

Una vez que la letra está protestada, el tenedor reclama el pago mediante un documento llamado cuenta de resaca y donde constan las cantidades adeudadas (nominal de la letra, gastos de protesto y recambio).

Her er der tilsyneladende sket en sammenblanding af begreberne cuenta de resaca og letra de resaca.

Alt i alt må jeg desværre konkludere, at jeg ikke kan anbefale Español para el comercio internacional på grund af ovenstående. 